UDC 811.111'255.4:81'282

DOI https://doi.org/10.32838/2663-6069/2020.4-3/13

Svider I. A.

Kamianets-Podilskyi Ivan Ohiienko National University

\title{
TRANSLATION OF COMPLIMENTS: GENDER ASPECT
}

In the article compliment is characterized as a unity of speech act, gender, social and psychological interaction. The author defines main ways for compliment behavior to be realized in cross-gender communication. Compliment is regarded as an important constituent of speech intercourse of native speakers of English, influencing the character of interpersonal mutual relations of communicants, the degree of their mutual understanding, and, hence, the success of the communication on the whole. The achievement of the present research lies in describing compliment not as a certain language form, having a definite set of functions, but as a unit of speech behaviour, as a special kind of speech acts, which has some structural, semantic and pragmatic features and, of course, gender peculiarities. The category of gender is a specific phenomenon in sociolinguistics since the mutual relationships between and within genders affect the choice of linguistic elements.

Regarding compliment frequency, males tend to compliment females far more often than they compliment other males. It should be noted that malelfemale interaction complimenting on ability or appearance takes the first place. In terms of pragmatic functions, females use compliments most often to establish, confirm or maintain solidarity while male compliments more often offer admiration. In order to express solidarity, membership or rapport, females give a higher number of compliments. Men, in contrast, use compliments rather sporadically. As far as receiving compliments is concerned, women predominate since they receive more compliments from other women and even from men.

The translation of gender compliments can be challenging. It demands the usage of various transformations and pragmatic adaptation of the utterance of the TL. If a compliment is given in accordance with etiquette, the translator may choose ready-made equivalents or functional analogues.

Key words: gender, compliment, interaction, relationship, translation, strategy.

Introduction. A successful studying of speech as a special form of social behaviour and revealing the general laws of communicative process is impossible without the deep complex analysis of the separate speech phenomena in the completeness of all their numerous aspects (language, social and psychological, gender, cognitive, ethno-cultural etc.). The compliment as an object of the linguistic analysis attracts attention of many researchers, e. g. the works of N. Wolfson and J. Manes, R. Herbert, B. Levandovskaja-Tomashchik, A. Kibrik, A. Wierzbicka, A. Pomerants. K. Aijmer, T. Ballmer, M. Bickhard etc.

An effective language user is competent not only in linguistics but in pragmatics as well. As Yule put it, "nothing in the use of the linguistic forms is inaccurate, but getting the pragmatics wrong might be offensive" [16, p. 5]. To be able to use a target language appropriately in terms of pragmatic competence, language users should employ a variety of speech acts. Complimenting is one of them.

Compliment corresponds with a concept of speech act (SA), as the given category is the main category in the speech ethnography and the technique of disclosing of the ethno-cultural specificity of speech behaviour, interrelations between language and social and cultural factors can't be developed without it. "The level of the speech act is a link between the usual levels of grammar and other components of speech event, as it combines both the linguistic form and social standards" [1, p. 139].

Compliment is also an important social strategy that functions as a starter for a conversation, allowing to follow meaningful social interactions. Each culture requires various kinds of speech act behavior. Blum-Kulka, House and Kasper found that "culturally colored interactional styles create culturally determined expectations and interpretative strategies, and can lead to breakdowns in intercultural and interethnic communication" [2, p. 30]. In other words, when people from different cultures interact, breakdowns in communication may happen due to signaling different speech act strategies that reflect the cultural distinctive interactional style. Complimenting is a particularly suitable speech act to investigate because it acts as a window through which we can view what is valued in a particular culture.

Act of complimenting is inevitably affected by social factors including gender. According to Tannen [14], gender differences are parallel to 
cross-cultural differences. Therefore, it is worthwhile to study the interactions between men and women, men and men, or women and women exchanging compliments and responses.

Linguists, sociologists, literary critics and philosophers have been interested in gender issues for a long period of time. In translation studies, only the first steps in this direction have been taken. We may observe some investigations devoted to the influence of gender on translation strategy (S. M. Anari), gender aspects of translation as feminine/masculine components of language (E. V. Polifuk), problems of grammatical translation in the context of gender studies (B. Karubi), the place of gender in translation studies (S. Simon), cultural interpretation of gender (L. von Flotow) etc. Gender aspects of compliment were also examined by M. Lazar, J. Holmes, R. Herbert, D. Tannen, R. Lakoff, J. Coates, P. Eckert, N. Wolfson.

Two important studies that focus on gender differences in complimenting are those by Holmes and Herbert $[6 ; 9]$. They found that the syntactic patterns and lexical choice employed by men and women were different. Based on the findings, they assumed that females use compliments for keeping solidarity, while males regard compliments as potential face threatening acts or actual assertions of praise.

As we see there are many investigations focused on gender aspect of compliments, but, unfortunately, in the sphere of translation this issue hasn't been paid much attention to.

Main research. It is widely recognized that female linguistic behavior is different from males. Holmes noted down that it is agreed that women tend to be more "facilitative, affiliative and cooperative" in interaction while men tend to be rather competitive and control-oriented [9, p. 125]. These different communication strategies are reflected in the use of compliments, too. The category of gender is a specific phenomenon in sociolinguistics since the mutual relationships between and within genders affect the choice of linguistic elements. Furthermore, these relationships differ from culture to culture, and therefore no universal rules can be presented.

Holmes, being one of the most distinguish English researcher of pragmatics, examined gender role in the process of responding to compliment and found that males would ignore or legitimately evade a compliment more often than females [8]. In his study on Polish compliments, A. Jaworski has stated that whilst females tend to exchange compliments to achieve relational solidarity, males often use compliments in order to negotiate in-group power relation [10].
Concerning the problem of giving compliments, women are true masters of this field, which is the logical outcome of both their general linguistic behavior and their perception of compliment function. While women perceive compliments rather as "positively affected speech acts expressing solidarity and positive politeness", men understand compliments as "evaluative judgements" or even as "face threatening features" in conversation [9, p. 122]. Since females, who are considered to be other-oriented, seek to express solidarity, membership or rapport, they give a higher number of compliments. Men, in contrast, use compliments rather sporadically.

Men and women differ even in the choice of the object of compliments. Four main topics may be observed in compliments: appearance, ability/performance, possessions, and personality/friendliness. Holmes has observed a few tendencies in complimenting: 1) women both give and receive more compliments on their appearance; 2) men compliment each other on possessions mostly [9, p. 131].

No wonder women choose the topic, which is clearly, and unambiguously an expression of solidarity and friendliness, i. e. appearance. Men, by contrast, tend to choose possessions as the object of their compliments, which can't be interpreted (as compliments) so unambiguously, since possession-oriented compliments may be interpreted as expressions of desire or envy.

The crucial factor in comparing two different approaches to compliments made by men and women lies in different perceptions of compliment function. In other words, women perceive mainly the affective or social function of compliments, while men rather perceive the referential function. This preference is reflected in almost all the aspects of compliments.

There are so many reasons which make a person alter their mind to utter and employ a compliment. Compliment and compliment response patterns appear to be completely different when the addresser and the addressee also have different genders. According to Coates, "Female speakers will use a higher proportion of prestige forms than male speakers. In other words, the prestige norms seem to exert a stronger influence on women than on men" [3, p. 64]. Two important studies that focus on gender differences in complimenting are those by Holmes and Herbert. They found that the syntactic patterns and lexical choice employed by men and women were different. Based on the findings, they assumed that females use compliments for keeping solidarity, while males regard compliments as potential face threatening acts or actual assertions of praise. E.g., by 
complimenting someone's taste in fashion, by saying "You look so pretty in that gown", this compliment may use as facilitating conversation [6, p. 67].

Summing up the main results of scholars, involved in researching a compliment, we may outline the following:

1) Women use compliments to each other obviously more than they do to men or men do to each other;

2) Women are more likely to receive compliments than men. It means that complimenters may be aware of the risk of discomfiting men with a FTA (Face Threatening Act) that can be explained as the act that infringe on the hearer' need to maintain his/her selfesteem and be respected [16, p. 120];

3) Women compliment each other on appearance more than on any other topic, whereas, between male, compliments on possessions are used more often;

4) Compliments tend to focus on skills or performance as solidarity signals for males, while compliments reinforce appearance regarded as solidarity signal for females;

5) Women and men interpret compliments differently. Women seem to use compliments to establish, maintain and strengthen relationship, while men use compliments as encouragement or evaluative feedback $[9 ; 13 ; 15 ; 17]$.

Hence, the results show the strong effects of both culture and gender on responding to a compliment. For these phenomena, many linguists also give some reasons: 1) From the point of character aspect, women seek connections and involvement in conversation, while men seek independence and hierarchy. 2) Due to the socialization aspect, women and men have different experiences from their childhood. Women tend to be more cooperative and relatively close in interactions, while men tend to be more competitive and control-oriented. 3) According to the power and society status aspect, men are usually the dominant in the society, and they are the center in public, wherever they are in the economy, politics and so on. Men are considered to be more powerful, so they show more competitiveness, than women [7, p. $157 ; 12$, p. 31].

The ritual of exchanging compliments is a purely English feature. Often, the British start a conversation exchanging the compliments to maintain the relationship. In this case, the conversation can jump from topic to topic - outfit, appearance, communication skills, children, talents etc. During the exchange of compliments, the interlocutors would compete in the expression of modesty (selfdenial), here we can observe a grain of hypocrisy (indirectness), as the whole communicative scenario is quite predictable. This act is very common for female beings. E.g.: "I like your dress," remarked Mrs. McKee, "I think it's adorable". - Mrs. Wilson rejected the compliment by raising her eyebrow in disdain. "It's just a crazy old thing," she said. "I just slip it on sometimes when I don't care what I look like" [4]. Self-denial (belittle) is observed as a reaction to the compliment. Women tend to do it more often than men, what can be seen in the following translation: "Місіс Вільсон відхилила комплімент, зневажливо звівши одну брову. - Ет, це вже старі лахи, - мовила вона. - Цю сукню я вже не ношу - надягаю хіба тоді, коли мені байдуже, як виглядаю" [5].

While translating into Ukrainian, the lexical structure of the compliment may be changed. First of all, adjectives often lose their vivid emotional expression: E.g. "I certainly am awfully glad to see you again" [4] and "Мені дуже приємно бачити вас знову" [5].

The translator can use the emphatization to show the true delight of the speaker: "I like your dress, remarked Mrs. McKee, - I think it's adorable" [4]. "Мені так подобається ваша сукня, - сказала місіс Маккі. - Від неї очей не відірвеш" [4]. We should note that the corresponding lexico-grammatical form I like/love is not rendered in Ukrainian directly, and receives an additional component the adverb " or somebody. At the same time, the second part of the compliment is conveyed by a phraseological unit to make an emotive influence on the recipient. In the SL text the characteristics of the object and person are given, in the TL text the attitude of the speaker and his emotional message used to provoke a certain (positive) reaction are stated.

InEnglish there are common and generally accepted literary or etiquette formulas. Among them we can admit offers or proposals and negative interrogative structures, the main function of which is rather to express a pleasant information for the interlocutor than to actually create a question. As a rule, they don't cause any difficulties in translation: "I love to see you at my table, Nick. You remind me of a - of a rose, an absolute rose. Doesn't he?" [5] - “Як мені присмно бачити тебе за нашим столом, Ніку! Знаєш, ти схожий на... на троянду, так, саме на троянду. Правда ж?" [4]. Although the addressee doesn't understand and agree with the disguised compliment, expressed by a metaphorical comparison, he has no doubts about good intentions of the interlocutor and feels positive emotions.

We are to differentiate direct (explicit) and indirect (implicit) compliments. The direct compliment 
accentuates positive traits of the interlocutor: "She's a nice girl," said Tom after a moment" [4]. - "Вона славна дівчина, - сказав Том по хвилі" [5]. - "Fine fellow, isn't he? Handsome to look at and a perfect gentleman" [4]. - «Чудовий хлопець, правда? І з виду приємний, i джентльмен до самих кісток» [5]. In this case functional substitution is used to preserve the same semantic and pragmatic meaning.

In most cases indirect compliments have nothing to do with the person himself, but focus on the achievements or progress of the interlocutor (children, property, real estate, job promotion etc.) without directly pointing to it. This fact is also proved by Kerbrat-Orecchioni, who noticed that "direct compliments are those that have to do directly with the hearer whereas indirect ones are those that have to do with a third person, closely associated with the hearer" [11, p. 57]: "That huge place THERE? - she cried pointing [4]. - «Невже оте громадисько - твій будинок? - вигукнула вона, показуючи пальцем» [5].

Taking into account a rather restrained nature of the British, we can say that the use of indirect compliments in language is quite common. While translated into Ukrainian this meaningful aspect is sometimes lost, as we can observe in the example above.

Conclusions. The category of gender is a specific and complex phenomenon that can have a significant influence on the choice and type of compliments. In different countries and societies the gender compliments and responses may vary and this fact is inevitably reflected in the language. Through this study we can affirm that in most cases women give and receive significantly more compliments than men do (both in spoken and written utterances). Moreover, women prefer complimenting peers of their own gender. Considering the crossgender perspective, it is more common to notice a compliment given by a man to woman than vice versa. These behavioral patterns are logical outcomes of different perceptions of compliment function by the two genders.

Translation of compliments is formed under the influence of national and historical factors. In a broad sense, translation depends on national culture of the receptor, which is usually genderlabeled, depending on its feminine/masculine orientation. The choice of adequate compliment translation depends on its stereotypical features. The translation of non-typical compliments demands the usage of various transformations and pragmatic adaptation of the utterance of the TL. In etiquette formulas the translator chooses readymade equivalents or functional analogues, particular for corresponding communicative situation in the TL.

\section{References:}

1. Bach K., Harnish R. Linguistic communication and speech acts. Cambridge (Mass.) : MIT Press, 1980. 327 p.

2. Blum-Kulka S., House J., Kasper G. Cross-cultural pragmatics : Requests and apologies. Norwood, NJ : Ablex, 1989. $300 \mathrm{p}$.

3. Coates J. Women, men and language : A sociolinguistic account of gender differences in language. Harlow : Longman, 2004. $245 \mathrm{p}$.

4. Fitzgerald F. S. The Great Gatsby. URL: http://gutenberg.net.au/ebooks02/0200041h.html

5. Fitzgerald F. S. Velykyi Hetsbi (in Ukrainian). URL: https://www.ukrlib.com.ua/world/printit.php?tid=1164

6. Herbert R. K. Sex-based Differences in Compliment Behavior The Sociolinguistics Reader. London : Arnold, 1998. Volume 2 : Gender and Discourse. P. 53-75.

7. Holmes J. An introduction to sociolinguistics. New York : Routledge, 2013. 512 p.

8. Holmes J. The role of compliments in female-male interaction. Using English : From conversation to canon. London : Open University, 1996. P. 32-36.

9. Holmes J. Women, Men and Politeness. London : Longman, 1995. 264 p.

10. Jaworski A. "This is not an empty compliment!" Polish compliments and the expression of solidarity. International Journal of Applied Linguistics. Oxford : Blackwell, 1995. Volume 5. P. 63-94.

11. Kerbrat-Orecchioni C. Les interactions verbales. Variations culturelles et échanges rituels. 1994. Volume 3. Paris : Armand Colin. 347 p.

12. Lazar M. Feminist Critical Discourse Analysis : Studies in Gender, Power and Ideology. New York : Palgrave Macmillan, 2005. 272 p.

13. Manes J. Compliments : A Mirror of Cultural Values. Sociolinguistics and Language Acquisition. Rowley : Newbury, 1983. P. 96-102.

14. Tannen D. You just don't understand : Women and men in conversation. New York : Ballantine Books, $1990.352 \mathrm{p}$.

15. Wolfson N. An empirically based analysis of complimenting in American English. Sociolinguistics and language acquisition. Rowley, Massachusetts : Newbury House, 1983. P. 82-95. 
16. Yule G. Pragmatics. New York : Oxford University Press, 1996. 152 p.

17. Yule G. The study of language. London : Cambridge University Press, 1996. 308 p.

\section{Свідер І. А. ГЕНДЕРНИЙ АСПЕКТ ПЕРЕКЛАДУ КОМПЛІМЕНТІВ}

У статті подана характеристика компліментарного висловлювання як сукупності мовленнєвої дії, гендерної та соиіально-психологічної взаємодії. Автор визначає основні способи реалізації компліментарної поведінки в міжгендерному спілкуванні. Комплімент розглядається як важлива складова мовного спілкування носї̈в англійської мови, що впливає на характер міжособистісних взаємовідносин комунікантів, ступінь їх взаєморозуміння, а отже, і на успіх спілкування загалом. Досягнення нашого дослідження полягає в описі компліменту не як певної мовної форми, що має визначений набір функиій, а як одиничі мовленнєвої поведінки як особливого виду мовленнєвого акту, щзо має деякі структурні, семантичні, прагматичні та, звичайно, гендерні особливості. Категорія гендеру є специфічним явищем у соціолінгвістиці, оскільки стосунки між статями та всередині них впливають на вибір мовних елементів.

Що стосуеться частоти компліментів, то чоловіки, як правило, роблять компліменти жінкам набагато частіше, ніж компліменти іншим чоловікам. Слід зазначити, щяо компліменти щодо здібностей чи зовнішнього вигляду займають перше місце. Щодо прагматичних функцій, то жінки найчастіше використовують компліменти для встановлення, підтвердження або підтримки стосунків, тоді як чоловічі компліменти частіше викликають захоплення. Щоб висловити солідарність, членство чи стосунки, жінки дають більшу кількість компліментів. Чоловіки, навпаки, використовують компліменти досить епізодично. Що стосується отримання компліментів, то тут жінки мають перевагу, оскільки вони отримують більше компліментів від інших жінок і навіть від чоловіків.

Переклад гендерних компліментів може бути складним завданням. Це вимагає використання різноманітних трансформачій та прагматичної адаптації висловлювання на мові перекладу. Якще комплімент виголошується відповідно до правил етикету, перекладач може вибрати готові еквіваленти або функиіональні аналоги.

Ключові слова: гендер, комплімент, взаємодія, стосунки, переклад, стратегія. 